\title{
$=-\frac{2}{2}$
}

NASA Technical Memorandum 102536

\section{Evaluation of Thermal and Mechanical Loading Effects on the Structural Behavior of a $\mathrm{SiC} / \mathrm{Titanium} \mathrm{Composite}$}

Joseph E. Grady and Bradley A. Lerch

Lewis Research Center

Cleveland, Ohio

Prepared for the

31st Structures, Structural Dynamics and Materials Conference

cosponsored by the AIAA, ASME, ASCE, ĀHS, and ASC

Long Beach, California, April 2-4, 1990

\section{NASA \\ (NASA-TM-10?530) EVALUATION OF THERMAL AND \\ N90-20139 MECHANICAL LUAUING FFFECTS ON THE STRUCTUPAL BEHAVIOR OF A SIC/TITANIUM COMPOSITE (NASA) $15 \mathrm{P}$


EVALUATION OF THERMAL AND MECHANICAL LOADING EFFECTS ON THE STRUCTURAL

\author{
BEHAVIOR OF A SIC/TITANIUM COMPOSITE \\ Joseph E. Grady and Bradley A. Lerch \\ National Aeronautics and Space Administration \\ Lewts Research Center \\ Cleveland, Ohto 44135
}

\begin{abstract}
SUMMARY
Composite specimens of titanium-15-3 matrix reinforced with continuous SCS-6 stlicon carbide fibers were tested under a varlety of thermal and mechanical loadings. A combined experimental/finite element approach was used to estimate the effective in-situ modulus of the matrix material and to evaluate changes in modulus due to the applied loads. Several fiber orientations were tested. Results indicate that the effect of the thermal loads on composite stiffness varies with fiber orientation. Applications of this method to test specimens damaged by uniaxial tension, thermal cycling, and isothermal fatigue loadings are used to fllustrate that by monitoring overall structural behavior, changes in stiffness caused by thermomechanical loading can be detected.
\end{abstract}

\title{
INTRODUCTION
}

The mechanical behavior of composite materials depends on the properties of the fiber and matrix constituents. Because of inhomogenelties due to the addition of the fibers and due to thermal loadings which occur during the fabrication process, the in-situ matrix properties of the SiC/Ti-15-3 composite can vary significantly from those of the monolithic matrix (ref. 1). Matrix stiffness properties, as well as the integrity of the fiber/matrix bond, will also change as the composite material deforms under applled mechanical and thermal loads.

In this paper, an indirect measurement of the effective in-situ matrix modulus is obtained, using the results of experimental tests together with finite element analysis of the composite test specimens. The term "effective matrix modulus" is used to account for changes in the measured stiffness of the composite. These changes could be due to a varlety of damage modes. In this article, however, all damage will be incorporated into and accounted for by changes in matrix modulus. The resonant frequencies of the individual specimens are measured by vibration testing. Based on the measured frequencies, the effective modulus of the test specimens is determined by finite element analysis. This indirect measurement technique is applied to each individual test specimen in its original, as-fabricated condition, as well as after a heat treatment, and thermal or mechanical loads are applied. The results therefore show how the effective matrix modulus changes with the different applied loads. 


\section{EXPERIMENTAL PROCEDURE}

\section{Material Fabrication}

The composite was fabricated in a proprietary process in which alternating layers of SIC (SCS-6) fibers and foils of $\mathrm{TI}-15 \mathrm{~V}-3 \mathrm{Cr}-3 \mathrm{Sn}-3 \mathrm{Al}$ ( $\mathrm{Ti}-15-3$ ) were consolidated. Elght rows of fibers were used, yielding a total composite thickness of approximately $0.08 \mathrm{in}$. The nominal fiber volume fraction was 34 percent. Additional microstructural details of the material can be found in references 2 and 3 . Several fiber orientations were used in this study, consisting of a $[90]_{8},[ \pm 30]_{2 s},[ \pm 45]_{2 s},[0 / 90]_{2 s}$, and $[90 / 0]_{2} s$. The $[0 / 90]$ had $0^{\circ}$ plies on the outer surfaces, whereas the [90/0] had $90^{3}$ plles on the outer surfaces. Test specimens, as shown in figure $1(a)$, of nominal dimension 6 by 0.5 by 0.08 in. and containing a reduced gauge section were cut from the finlshed panels.

\section{Vibration Testing}

Test specimens were cantllevered in mechanical grips that clamped 2 in. along one end of the specimen, as shown in figure 2, A 1 ightweight (142 mg) accelerometer was attached to the mid-span of the specimen using a thin layer of MIL-A-46050C cyanoacrylate adhesive. Free vibration response of the cantilevered specimen was recorded digitally on a spectrum analyzer, and simultaneously displayed on an oscilloscope, as shown in figure 3 . Figures 3 and 4 show representative measurements of the vibration response for a typical specimen. Figure 3 shows, as displayed on the osclilloscope, the acceleration response in the time domain to a translent load applied at the free end of the specimen. The corresponding frequency response is shown in figure 4 . The frequency data was processed using a Hanning window for improved frequency resolution, and was obtalned by RMS averaging the results of ten separate tests for each specimen. After the slgnal averaging was performed, resonant frequencies were identifled by digitally locating the peaks in the frequency response signal. Measurements taken in this manner proved to be both extremely sensitive to material changes (e.g., cracking, debonding) caused by the applied loads, and repeatable to within a \pm 0.2 percent measurement error.

\section{ANALYSIS}

\section{Material Properties}

Stiffness coefficients for the 8-ply composite test specimens were calculated from the fiber and matrix properties given in table I as follows. For a single unidirectional ply with fibers oriented in the 1-direction, the elastic constants given by simple rule-of-mixtures calculations are (ref. 4): 


$$
\begin{gathered}
E_{11}=V_{f} E_{f}+V_{m} E_{m} \\
v_{12}=V_{f} v_{f}+V_{m} v_{m} \\
E_{22}=\left[V_{f} / E_{f}+V_{m} / E_{m}\right]^{-1} \\
G_{12}=\left[V_{f} / G_{f}+V_{m} / G_{m}\right]^{-1} \\
\rho=V_{f} \rho_{f}+V_{m} \rho_{m}
\end{gathered}
$$

where the subscripts $f$ and $m$ refer to fiber and matrix, $E, G, v$, and $p$ are the Young's Modulus, Shear Modulus, Poisson's ratio and mass density, respectively, and $V$ is the volume fraction of the respective constituent.

Assuming a state of plane stress in the $1-2$ plane, the unidirectional ply stress-strain relations are given by:

$$
\left\{\begin{array}{l}
\sigma_{1} \\
\sigma_{2} \\
\sigma_{6}
\end{array}\right\}=[Q]\left\{\begin{array}{l}
\varepsilon_{1} \\
\varepsilon_{2} \\
\varepsilon_{6}
\end{array}\right\}
$$

where the subscripts 1, 2 denote normal in-plane stresses and strains; and 6 denotes in-plane shear. In terms of the engineering constants,

$$
[Q]=[S]^{-1}
$$

where

$$
\begin{array}{lll}
S_{11}=1 / E_{11} & S_{12}=-v_{12} / E_{11} \\
S_{22}=1 / E_{22} & S_{13}=S_{23}=0
\end{array}
$$

Stress and strain transformation equations are used to calculate [Q] in equation (2) for unidirectional ply oriented at an arbitrary angle $\theta$ to the 1 -direction, and laminated plate theory (ref. 5 ) is then used to calculate membrane and bending stiffness coefficients for the 8-ply composite with arbitrarily oriented plies. These coefficients are then used as the elastic anisotropic constants in the finite element analysis.

The simplifying assumptions inherent in equation (1) are that the fiber/ matrix bond is strong and the deformation is elastic. The latter assumption may be adequate in this case since the modulus calculations are being used to predict composite stiffness for small amplitude vibrations. The actual strength of the fiber/matrix bond in unknown. 


\section{Finite Element Analysis}

A finite element modal analysis was performed for each test specimen using MSC/NASTRAN (ref. 6). Two-dimensional, isoparametric shell elements with or thotropic membrane and bending stiffness were used to model the composites. A representative finite element mesh used to analyze the cantilevered tensile specimen with a reduced gage section is shown in figure $l(b)$.

\section{RESULTS AND DISCUSSION}

\section{Numerical Convergence}

A preliminary study was performed to determine the number of finite elements required for a converged modal solution. The results shown in figures 5 (a) and (b) are the natural frequencies measured and calculated for a $[ \pm 30]_{2} \mathrm{~s}$ specimen of dimension 6 by 1 by $0.075 \mathrm{in}$. These figures indicate that the calculated bending frequencies are sensitive to the number of elements in the longitudinal direction. A converged solution is obtained with 30 longitudinal elements, and these results are given in table II. Bending stiffness is underestimated with coarser meshes because reduced integration is used to calculate the element stiffness (ref. 6). Thus, 30 longitudinal elements were used in subsequent calculations.

\section{Vibration Analysis}

Vibration tests were performed several times for a few, selected specimens to determine the measurement repeatability. The measured values for natural frequencies were found to vary a maximum of 0.2 percent from one test to another. Shifts in frequency due to applied thermal and mechanical loads were usually on the order of 2 to 3 percent, so this degree of measurement accuracy was considered acceptable.

The placement of the accelerometer on the specimen, as shown in figure 2, was chosen so as to detect the flexural (bending) motion of the specimen rather than the torsional (twisting) motion. Therefore, in the results presented here, the frequencies are all associated with bending modes. The lowest frequency range scanned for the specimen used in figure 5 was 1 to $1.2 \mathrm{kHz}$, so no data was taken for the $180 \mathrm{~Hz}$ bending mode. The dashed lines are the measured resonant frequencies for each of the modes. The calculated frequencies were determined by varying the matrix modulus from 9 to 15 Ms 1 until the frequencles calculated in the finite element analysis were within 1 to 2 percent of the measured values. The matrix modulus giving the best agreement with the measured values for this specimen was $10.3 \mathrm{Msi}$. The results in flgures $5(a)$ and (b) and table II indicate that the frequencies calculated for the first six bending modes correspond well with the measured values.

\section{Heat Treating}

In figure 6 , the effective matrix modulus is presented graphically for each of the ply orientations tested. The average matrix modulus, both before and after heat treating for $24 \mathrm{hr}$ at $1292^{\circ} \mathrm{F}$ in vacuum, is $10.7 \mathrm{Ms}$. This is 
somewhat lower than the normal modulus of $12.5 \mathrm{Ms} 1$ determined from a tenslle test for monolithic Ti-15-3 (ref. 3). The two methods may yleld different values. This is currentiy under investigation. Further, a perfect bond between fiber and matrix has been assumed in the stiffness calculations given in equation (1). Any imperfections in the fiber/matrix bond will lower the composite stiffness, and therefore appear as a lower matrix modulus in this model. Similarly fabrication-induced residual stresses can lead to cracking in the matrix or fiber/matrix interphase region. Both types of damage will lower the effective matrix modulus in these calculations. Nevertheless, the modulus values given here can be used effectively to compare the relative damage states of the different test specimens. The data in figure 6 are given in tables III to VII.

If $\Delta \Theta$ is the difference in ply orientation for neighboring plies of the composite, i.e.

$$
\Delta \Theta=\Theta_{1}-\Theta_{i+1}
$$

where the subscript, $\mathfrak{i}$, refers to the ply number, the data in figure 6 indicate that heat treatment effectively increased the composite stiffness when $\Delta \theta=60^{\circ}$ or less (i.e. [ $[30]$ or [90] fiber orientations), and decreased composite stiffness when $\Delta \Theta=90^{\circ}$ (i.e. [ \pm 45$],[0 / 90]$ and [90/0] fiber orientations). These 11 mited data suggest that the response of the composite to heat treatment is dependent on the residual stress state and on the lateral constraining effect that the plles impose on one another.

Tensile tests on monolithic $\mathrm{Ti}-15-3$ (ref. 3) indicate that al though tenslle strength and fallure strain are affected by the heat treatment, the elastic modulus is not significantly changed from its original value of approximately $12.5 \mathrm{Ms}$. The changes in effective matrix modulus of the composite caused by heat treating, therefore, are most likely due to changes in the integrity of the fiber/matrix bond that could occur during thermal loading of the composite. The integrity of this bond could be affected by the residual stress state within the individual plles and would therefore vary as a function of the ply stacking sequence. A detailed analysis of the residual stress state is in progress and will be reported subsequently.

\section{Tensile Load}

A $144 \mathrm{ksi}$ tensile load was applied to a $[ \pm 30]$ specimen after it was heat treated. The test was performed in strain control, and at a constant strain rate of $10^{-4} \mathrm{sec}^{-1}$. The maximum strain level reached was 1.5 percent, which is very close to the failure strain for this fiber orientation. An additional vibration test was performed on the specimen after the tensile load was removed. Effective matrix modulus values were back-calculated, based on the data given in table III are shown in figure 7 . The matrix modulus was 11.6 Ms 1 after heat treating but dropped to $10.3 \mathrm{Ms} 1$ after applying the tensile load, suggesting that some damage to the composite was caused by the tensile load. Micro-focus $x-r a y$ analysis was performed on the damaged specimen. This analysis indicated that damage in the form of cracks was concentrated in the area highlighted in figure 8 . Examination of the damaged area using a Scanning Electron Microscope (SEM) revealed the fallure detalls shown in figure 8 . As indicated in these micrographs, the outer matrix layer exhibits cracking. The 
cracking occurs on both sides of the specimen in the area indicated by the dashed square. A high magnification of these cracks indlcate that the fibers within the crack ( $1 . e$. , the first fiber row) remain intact. Whether these cracks propagated through the thickness of the specimen is at this time unknown.

\section{Fatigue Load}

After heat treatment, a $[ \pm 45]$ specimen was fatlgue tested at a frequency of $0.1 \mathrm{~Hz}$ for 195 tension-tension cycles at $800^{\circ} \mathrm{F}$. The applied mean stress, $\sigma_{\mathrm{m}}$, was $17.3 \mathrm{ksl}$ and the stress range, $\Delta \sigma$, was $32.9 \mathrm{ksi}$. The stress ratio, $\sigma_{\min } / \sigma_{\max }$, was therefore 0.05 . For these loading conditions, 195 cycles is approximately $T$ percent of the expected low cycle fatigue life of the composite (ref. 7). The test data are given in table IV and the calculated modulus (10.7 Ms 1 ) is compared to the as-received ( $11.4 \mathrm{Ms} i$ ) and heat treated (11.0 Msi) values in figure 9. The results indicate that some degradation was caused by the fatigue loading. No metallographic inspection of the damaged specimen has yet been performed, so no supporting data is avallable to identify the type and location of the damage. However, no visible cracking was observed on the outer surfaces of the specimen.

\section{Thermal Cycling}

Cyclic thermal loading may cause cracking at or near the fiber/matrix interface region due to the mismatch in thermal expansion coefficient between fiber and matrix. To evaluate this effect, the [90/0] specimen was exposed to 2000 thermal cycles from 200 to $1000^{\circ} \mathrm{F}$ by cycling the specimen into and out of a furnace at a rate of 0.17 cycles $/ \mathrm{min}$. The test results are tabulated in table $V$ and are shown graphically in figure 10 . They indicate that the thermal cycling had a negligible effect on the composite stiffness. The difference between as-recelved and heat treated properties indicate that some damage may have been introduced during heat treatment, but the material was not significantly further damaged by the cyclic thermal load.

Further evidence to this effect was obtained by tensile testing several [0/90] specimens to fallure. A typical specimen that had not been exposed to the thermal cycling had measured values of $22 \mathrm{Ms} 1,146 \mathrm{ks} 1$ and 1.04 percent for the modulus, $E_{11}$, ultimate tensile strength, and fallure strain, respectively; while an otherwise identical specimen had corresponding values of $21 \mathrm{Msi}, 137 \mathrm{ks} /$ and 0.98 percent after being exposed to the cyclic thermal load. These results indicate that either no material degradation was caused by the thermal cycles, or that both the vibration analysis and tensile test were insufficient for detecting the small amount of damage which may have occurred during thermal cycling.

\section{SUMMARY OF RESULTS}

A combined experimental/analytical technique that uses the results of vibration testing together with finite element analysis, was demonstrated and used to evaluate the degradation of mechanical properties of SiC/Ti-15-3 composites. The effects of heat treatment on specimens of varying ply orientation were analyzed, and representative results were presented that illustrate 
the effects of monotonic tenstle loading, fatigue loading, and thermal cycling on composite stiffness.

The results for the five different ply orlentations considered, indicated that the effective in-situ modulus of the matrix material in the as-received condition was an average of 15 percent lower than the monolithic value. In addition, the effect of heat treatment on the composite stiffness varied with ply stacking sequence.

\section{REFERENCES}

1. Bahe1-EI-DIn, Y.A. and Dvorak, G.J., "Plastic Deformation of a Laminated Plate with a Hole," Journal of Applied Mechanics, Vol. 47, No. 4, Dec. 1980, pp. 827-832.

2. Lerch, B.A., Hull, D.R., and Leonhardt, T.A., "As-Received Microstructure of a SiC/Ti-15-3 Composite," NASA TM-100938, 1988.

3. Lerch, B.A., Gabb, T.P., and MacKay, R.A., "Heat Treatment Study of the SIC/Ti-15-3 Composite System," NASA TP-2970, 1990.

4. Jones, R.M., Mechanics of Composite Materials, Scripta Book Co., Washington, $\mathrm{DC}, 1975$.

5. Whitney, J.M. , Structural Analysis of Laminated Anistropic Materials, Technomic Pubilishing Co., Lancaster, PA, 1987.

6. MacNeal, R.H., ed., The NASTRAN Theoretical Manual, (Level 15.5), MacNeal-Schwendler Corp., Los Angeles, CA, 1972.

7. Lerch, B.A., On-golng research, NASA-Lewis Research Center, Cleveland, $\mathrm{OH}$. 
TABLE I. - FIBER AND MATRIX

ELASTIC PROPERTIES

\begin{tabular}{|l|l|l|}
\hline & Fiber & Matrix \\
\hline$E,($ Msi) & 62 & $9-15$ \\
$G,($ Msi) & 26 & $E / 2(1+v)$ \\
$v$ & 0.19 & 0.32 \\
$\rho,\left(1 \mathrm{~b} / \mathrm{in}^{3}\right)$ & 0.108 & 0.172 \\
$\alpha,\left(\mathrm{x} 10^{-6} /{ }^{\circ} \mathrm{F}\right)$ & 2.7 & 4.7 \\
\hline
\end{tabular}

TABLE II. - SPECIMEN $\# 25[ \pm 30] 2 \mathrm{~s}$ FREQUENCY DATA

[m - Measured value $(\mathrm{Hz}) ; \mathrm{c}$ - calculated value $(\mathrm{Hz})$.]

\begin{tabular}{|c|c|c|c|}
\hline \multirow{2}{*}{$\begin{array}{l}\text { Vibration } \\
\text { mode }\end{array}$} & \multicolumn{3}{|c|}{ As-received condition } \\
\hline & $\omega_{m}$ & $\omega_{c}{ }^{*}$ & $\begin{array}{c}\text { Percent } \\
\text { error }\end{array}$ \\
\hline $\begin{array}{l}1 \\
2 \\
3 \\
4 \\
5 \\
6\end{array}$ & $\begin{array}{rr}-1 & 131 \\
3 & 190 \\
6 & 212 \\
10 & 270 \\
15 & 300\end{array}$ & $\begin{array}{rl} & 181.9 \\
1 & 136 \\
3 & 188 \\
6 & 274 \\
10 & 410 \\
15 & 585\end{array}$ & $\begin{array}{l}\overline{0.4} \\
0.1 \\
1.0 \\
1.4 \\
1.9\end{array}$ \\
\hline
\end{tabular}

${ }^{\star} E_{m}=10.3 \mathrm{Msi}$.

TABLE III. SPECIMEN \#24 [ \pm 30$]_{2}$ s FREQUENCY DATA

[m - Measured value $(\mathrm{Hz}) ; \mathrm{c}$ - calculated value $(\mathrm{Hz})$.

\begin{tabular}{|c|c|c|c|c|c|c|c|c|c|}
\hline \multirow{2}{*}{$\begin{array}{c}\text { Vibration } \\
\text { mode }\end{array}$} & \multicolumn{3}{|c|}{ As-received condition } & \multicolumn{3}{|c|}{ After heat treatment } & \multicolumn{3}{|c|}{ After tensile loading ${ }^{\dagger}$} \\
\hline & $\omega_{m}$ & $\omega_{c}^{\ddagger}$ & $\begin{array}{l}\text { Percent } \\
\text { error }\end{array}$ & $\omega_{m}$ & $\omega_{c}{ }^{\S}$ & $\begin{array}{l}\text { Percent } \\
\text { error }\end{array}$ & $\omega_{m}$ & $\omega_{c} \|$ & $\begin{array}{l}\text { Percent } \\
\text { error }\end{array}$ \\
\hline $\begin{array}{l}1 \\
2 \\
3 \\
4 \\
5 \\
6\end{array}$ & $\begin{array}{rr}-1 & 146 \\
-6 & 308 \\
10 & 393 \\
15 & 435\end{array}$ & $\begin{array}{rl} & 183.7 \\
1 & 144 \\
3 & 215 \\
6 & 325 \\
10 & 460 \\
15 & 743\end{array}$ & $\begin{array}{l}\overline{0.15} \\
0.27 \\
0.64 \\
2.0\end{array}$ & $\begin{array}{rr}-1 & 179 \\
6 & 471 \\
10 & 968 \\
16 & 260\end{array}$ & $\begin{array}{rl} & 188.7 \\
1 & 176 \\
3 & 304 \\
6 & 498 \\
10 & 748 \\
16 & 239\end{array}$ & $\begin{array}{l}\overline{0.25} \\
0.42 \\
2.0 \\
0.13\end{array}$ & $\begin{array}{rr}-1 & 138 \\
6 & 199 \\
10 & 713 \\
15 & 705\end{array}$ & $\begin{array}{rl} & 182.7 \\
1 & 138 \\
3 & 199 \\
6 & 292 \\
10 & 405 \\
15 & 651\end{array}$ & $\begin{array}{l}\overline{0.02} \\
1.5 \\
2.9 \\
0.3\end{array}$ \\
\hline
\end{tabular}

* 1292 of for $24 \mathrm{hr}$.

$\dagger 144 \mathrm{ksi}(1.5$ percent strain).

$\xi_{m}=10.5 \mathrm{Msi}$.

$\S_{E_{m}}=11.6 \mathrm{Msi}$.

$\|_{E_{m}}=10.3 \mathrm{Msi}$. 
TABLE IV. - SPECIMEN \#AI $[ \pm 45]_{25}$ FREQUENCY DATA

[m - Measured value $(\mathrm{Hz})$; c - calculated value $(\mathrm{Hz})$. ]

\begin{tabular}{|c|c|c|c|c|c|c|c|c|c|}
\hline \multirow{2}{*}{$\begin{array}{l}\text { Vibration } \\
\text { mode }\end{array}$} & \multicolumn{3}{|c|}{ As-received condition } & \multicolumn{3}{|c|}{ After heat treatment* } & \multicolumn{3}{|c|}{ After fatigue loading ${ }^{\dagger}$} \\
\hline & $\omega_{m}$ & $\omega_{c}{ }^{\ddagger}$ & $\begin{array}{c}\text { Percent } \\
\text { error }\end{array}$ & $\omega_{m}$ & $\omega_{c} \S$ & $\begin{array}{c}\text { Percent } \\
\text { error }\end{array}$ & $\omega_{m}$ & $\omega_{c} \|$ & $\begin{array}{c}\text { Percent } \\
\text { error }\end{array}$ \\
\hline $\begin{array}{l}1 \\
2 \\
3 \\
4\end{array}$ & $\begin{array}{l}\overline{958.3} \\
2754 \\
5448\end{array}$ & $\begin{array}{c}129.3 \\
958.6 \\
2807 \\
5479\end{array}$ & $\begin{array}{l}0.03 \\
1.9 \\
0.57\end{array}$ & $\begin{array}{l}-- \\
945.5 \\
2722 \\
5270\end{array}$ & $\begin{array}{c}127.4 \\
945.1 \\
2768 \\
5403\end{array}$ & $\begin{array}{l}-0.04 \\
1.7 \\
2.5\end{array}$ & $\begin{array}{l}934.5 \\
2691 \\
5280\end{array}$ & $\begin{array}{r}126.1 \\
935.0 \\
2739 \\
5346\end{array}$ & $\begin{array}{l}- \\
0.05 \\
1.8 \\
1.3\end{array}$ \\
\hline
\end{tabular}

* $1292{ }^{\circ} \mathrm{F}$ for $24 \mathrm{hr}$.

†195 LCF Cycles at $800^{\circ} \mathrm{F}$.

${ }^{\ddagger} E_{m}=11.4$ Msi.

$\S_{E_{m}}=11.0 \mathrm{Msi}$.

$\|_{E_{m}}=10.7 \mathrm{Msi}$.

TABLE $V$. - SPECIMEN \#C1 [90/0] $2 s$ FREQUENCY DATA.

[m - Measured value $(\mathrm{Hz}) ; c$ - calculated value $(\mathrm{Hz})$.

\begin{tabular}{|c|c|c|c|c|c|c|c|c|c|}
\hline \multirow{2}{*}{$\begin{array}{l}\text { Vibration } \\
\text { mode }\end{array}$} & \multicolumn{3}{|c|}{ As-received condition } & \multicolumn{3}{|c|}{ After heat threatment* } & \multicolumn{3}{|c|}{ After thermal cycling ${ }^{\dagger}$} \\
\hline & $w_{m}$ & $\omega_{c}^{\ddagger}$ & $\begin{array}{l}\text { Percent } \\
\text { error }\end{array}$ & $a_{m}$ & $\omega_{c} \S$ & $\begin{array}{l}\text { Percent } \\
\text { error }\end{array}$ & $\omega_{m}$ & $\omega_{c} \|$ & $\begin{array}{l}\text { Percent } \\
\text { error }\end{array}$ \\
\hline $\begin{array}{l}1 \\
2 \\
3 \\
4\end{array}$ & $\begin{array}{l}140.0 \\
1015 \\
2906 \\
5659\end{array}$ & $\begin{array}{l}140.0 \\
1024 \\
2980 \\
5798\end{array}$ & $\begin{array}{l}0.0 \\
0.86 \\
2.5 \\
2.5\end{array}$ & $\begin{array}{c}138.0 \\
999.0 \\
2875 \\
5583\end{array}$ & $\begin{array}{l}137.5 \\
1006 \\
2928 \\
5697\end{array}$ & $\begin{array}{l}0.4 \\
0.7 \\
1.8 \\
2.0\end{array}$ & $\begin{array}{l}137.5 \\
1031 \\
2969 \\
5808\end{array}$ & $\begin{array}{l}137.5 \\
1006 \\
2928 \\
5697\end{array}$ & $\begin{array}{l}0.0 \\
2.4 \\
1.4 \\
1.9\end{array}$ \\
\hline
\end{tabular}

* $1292^{\circ} \mathrm{F}$ for $24 \mathrm{hr}$.

t2000 cycles: $200^{\text {to }} 1000^{\circ} \mathrm{F}$.

$\#_{E_{m}}=10.7 \mathrm{Msi}$.

$\S_{E_{m}}=10.1$ Msi.

$\|_{E_{m}}=10.1 \mathrm{Msi}$.

TABLE VI. - SPECIMEN \#B] [0/90] 25 FREQUENCY DATA

[m - Measured value $(\mathrm{Hz})$; $\mathrm{c}$ - calculated value $(\mathrm{Hz})$.]

\begin{tabular}{|c|c|c|c|c|c|c|}
\hline Vibration & \multicolumn{3}{|c|}{ As-received condition } & \multicolumn{3}{c|}{ After heat treatment* } \\
\cline { 2 - 6 } & $\omega_{\mathrm{m}}$ & $\omega_{\mathrm{c}}^{\dagger}$ & $\begin{array}{c}\text { Percent } \\
\text { error }\end{array}$ & $\omega_{\mathrm{m}}$ & $\omega_{\mathrm{c}}^{\ddagger}$ & $\begin{array}{c}\text { Percent } \\
\text { error }\end{array}$ \\
\hline 1 & 151.3 & 151.4 & 0.07 & 150.3 & 151.1 & 0.6 \\
2 & 1102 & 1107 & 0.48 & 1093 & 1105 & 1.1 \\
3 & 3161 & 3222 & 1.9 & 3125 & 3216 & 2.9 \\
4 & 6130 & 6269 & 2.3 & 6081 & 6257 & 2.9 \\
\hline
\end{tabular}

* 1292 of for $24 \mathrm{hr}$.

$t_{E_{m}}=9.2 \mathrm{Msi}$.

${ }^{{ }^{*} E_{m}}=9.1 \mathrm{Msi}$. 


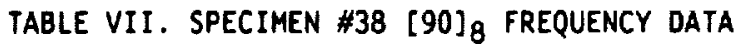

[m - Measured value $(\mathrm{Hz}) ; c$ - calculated value $(\mathrm{Hz})$.]

\begin{tabular}{|c|c|c|c|c|c|c|}
\hline \multirow{2}{*}{$\begin{array}{l}\text { Vibration } \\
\text { mode }\end{array}$} & \multicolumn{3}{|c|}{ As-received condition } & \multicolumn{3}{|c|}{ After heat treatment* } \\
\hline & $w_{m}$ & $\omega_{c}^{\dagger}$ & $\begin{array}{c}\text { Percent } \\
\text { error }\end{array}$ & $a_{m}$ & $\omega_{c}{ }^{\ddagger}$ & $\begin{array}{c}\text { Percent } \\
\text { error }\end{array}$ \\
\hline $\begin{array}{l}1 \\
2 \\
3 \\
4\end{array}$ & $\begin{array}{l}180.5 \\
3740 \\
7210\end{array}$ & $\begin{array}{l}180.6 \\
1319 \\
3832 \\
7479\end{array}$ & $\begin{array}{l}0.1 \\
2.4 \\
3.7\end{array}$ & $\begin{array}{l}182.0 \\
3800 \\
7328\end{array}$ & $\begin{array}{l}182.1 \\
1330 \\
3863 \\
7539\end{array}$ & $\frac{0.04}{1.6}$ \\
\hline
\end{tabular}

* 1292 of for $24 \mathrm{hr}$.

$t_{E_{m}}=11.3 \mathrm{Msi}$.

${ }^{\ddagger} E_{m}=11.5 \mathrm{Msi}$.

TABLE VIII. - TEST SPECIMEN GEOMETRY

[Dimensions in inches, weight in grams.]

\begin{tabular}{|c|c|c|c|c|c|c|}
\hline $\begin{array}{l}\text { Test specimen } \\
\text { designation }\end{array}$ & $\begin{array}{c}\text { Fiber } \\
\text { orientation }\end{array}$ & $\begin{array}{l}\text { Specimen } \\
\text { length }\end{array}$ & $\begin{array}{l}\text { Gage } \\
\text { length }\end{array}$ & $\begin{array}{l}\text { Gage } \\
\text { width }\end{array}$ & Thickness & Weight \\
\hline $\begin{array}{l}\text { A1 } \\
\text { B7 } \\
\text { C1 } \\
24 \\
25 \\
38\end{array}$ & $\begin{array}{c}{[ \pm 45] 2 s} \\
{[0 / 90]_{2 s}} \\
{[90 / 0]_{2 s}} \\
{[ \pm 30]_{2 s}} \\
{[ \pm 30]_{2} \text {. }} \\
{[90]_{8}}\end{array}$ & $\begin{array}{r}5.980 \\
\mathbf{5} .984 \\
\mathbf{5} .990 \\
\mathbf{5} .877 \\
\mathbf{5 . 8 7 2} \\
\mathbf{5 . 5 1 0}\end{array}$ & $\begin{array}{l}1.5 \\
1.5 \\
1.5 \\
(*) \\
(*) \\
1.0\end{array}$ & $\begin{array}{r}0.317 \\
.329 \\
.329 \\
.999 \\
.746 \\
.328\end{array}$ & $\begin{array}{r}0.076 \\
.077 \\
.077 \\
.075 \\
.075 \\
.083\end{array}$ & $\begin{array}{l}13.012 \\
13.374 \\
13.440 \\
30.105 \\
22.283 \\
13.765\end{array}$ \\
\hline
\end{tabular}

*Rectangular specimen. 


\section{ORIGINAL PAGE IS \\ OF POOR QUALITY}

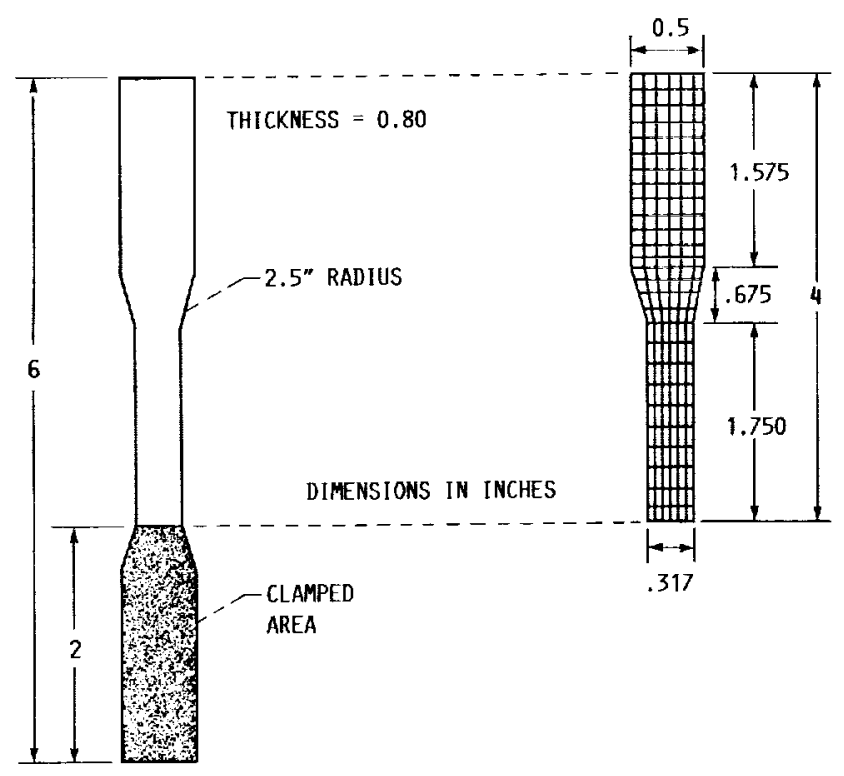

(a) TEST SPECIMEN.

(b) FINITE ELEMENT MODEL.

FIGURE 1. - TEST SPECIMEN GEOMETRY.

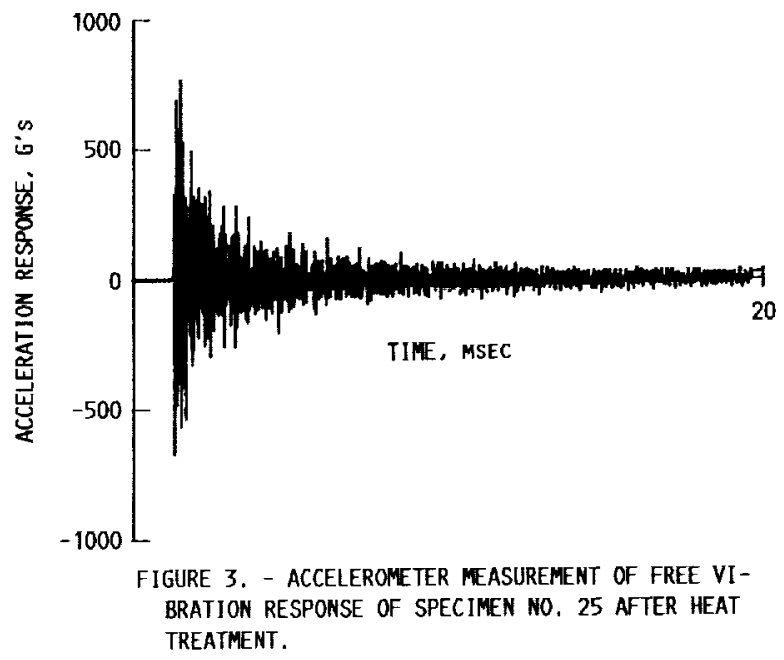

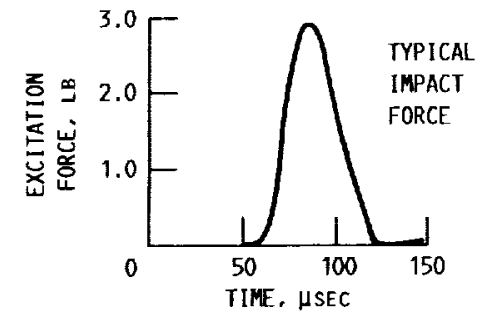

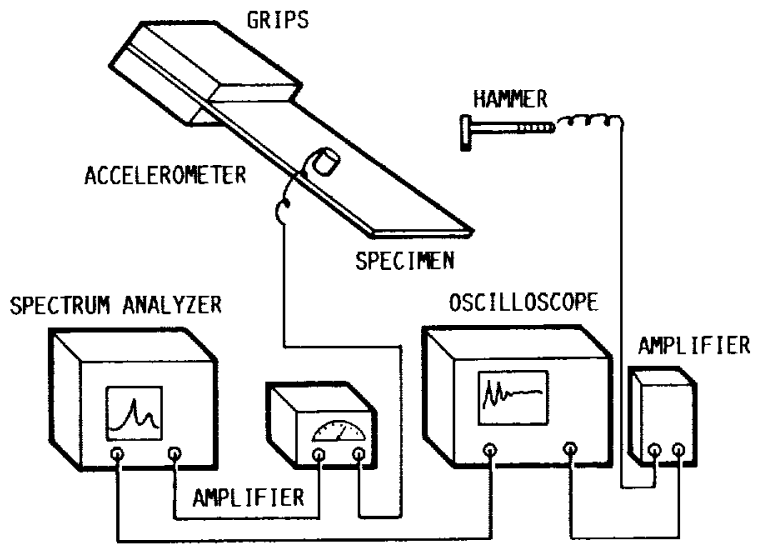

FIGURE 2. - EXPERIMENTAL APPARATUS.

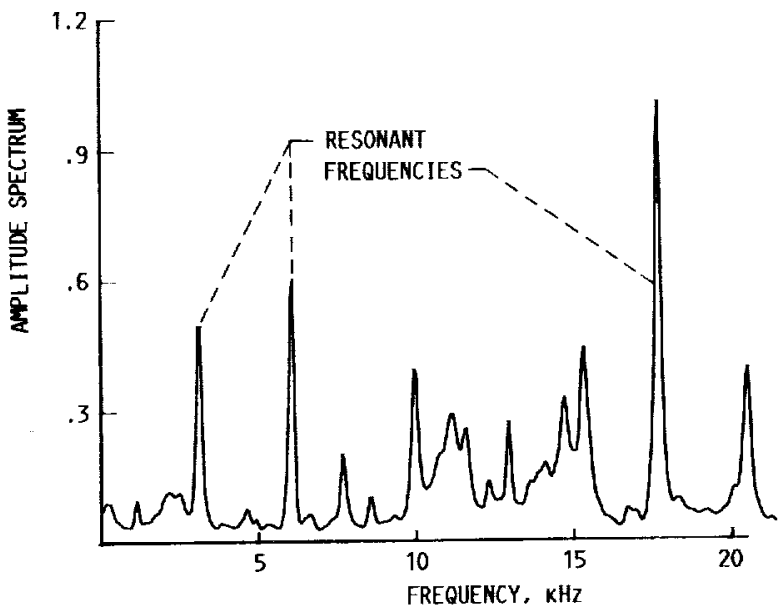

FIGURE 4. - AMPLITUDE SPECTRUM FOR SPECIMEN NO. 25 AFTER HEAT TREATMENT. 


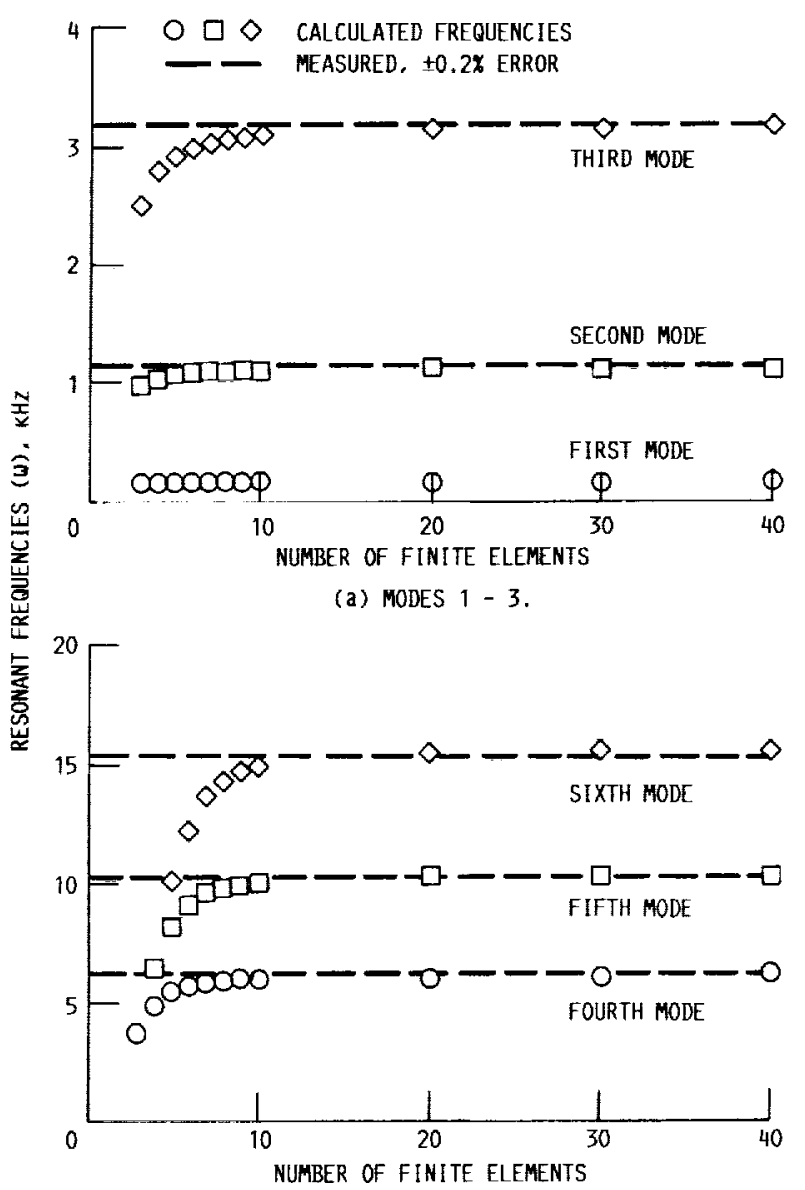

(b) MODES $4-6$.

FIGURE 5, - FINITE ELEMENT MESH CONVERGENCE: TEST SPECI-

MEN NO. 25. [ \pm 30$]$; MATRIX MODULUS: $10.3 \mathrm{Mst}$.
ORIGINAL P.AGE IS

OF POOR QUALITY

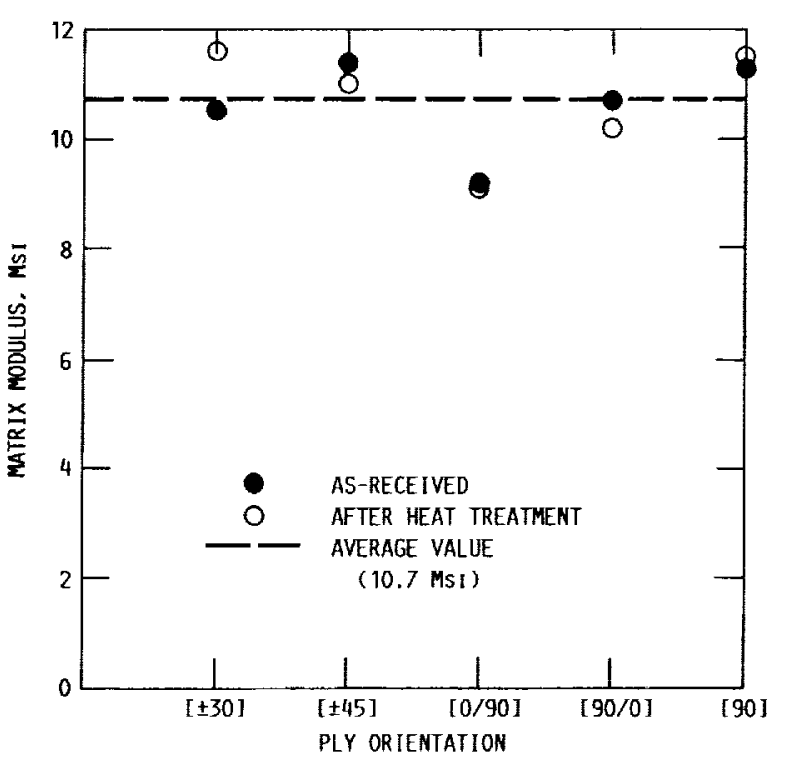

FIGURE 6. - CALCULATED MATRIX MODULUS BEFORE AND AFTER $24 \mathrm{HR} / 1292{ }^{\circ} \mathrm{F}$ HEAT IREATMENT.

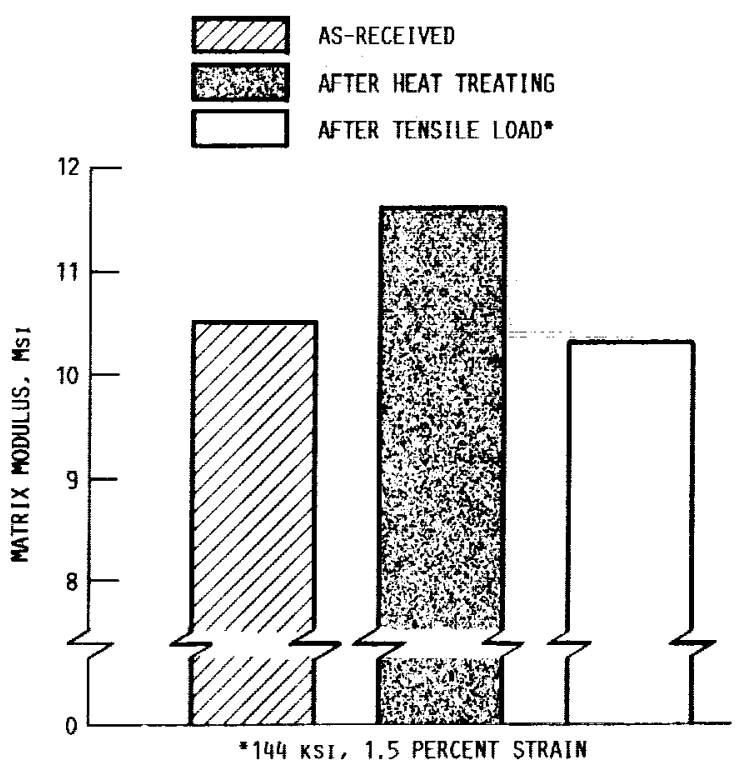

FIGURE 7. - CHANGE IN CALUCLATED MATRIX MODULUS FOR [\$30] SPECIMEN DUE TO HEAT TREATMENT AND TENSILE LOAD. 


\begin{tabular}{|c|c|c|c|}
\hline $\begin{array}{l}\text { 1. Report No. } \\
\text { NASA TM-102536 }\end{array}$ & 2. Government Accession No. & \multicolumn{2}{|c|}{ 3. Recipient's Catalog No. } \\
\hline \multicolumn{2}{|c|}{$\begin{array}{l}\text { Evaluation of Thermal and Mechanical Loading Effects on the Structural } \\
\text { Behavior of a SiC/Titanium Composite }\end{array}$} & \multicolumn{2}{|l|}{ 5. Report Date } \\
\hline \multirow{2}{*}{\multicolumn{2}{|c|}{$\begin{array}{l}\text { 7. Author(s) } \\
\text { Joseph E. Grady and Bradley A. Lerch }\end{array}$}} & \multicolumn{2}{|c|}{$\begin{array}{l}\text { 8. Performing Organization Report No. } \\
\text { E-5349 }\end{array}$} \\
\hline & & \multicolumn{2}{|l|}{$\begin{array}{l}\text { 10. Work Unit No. } \\
\text { 505-63-11 }\end{array}$} \\
\hline \multicolumn{2}{|c|}{$\begin{array}{l}\text { 9. Performing Organization Name and Address } \\
\text { National Aeronautics and Space Administration } \\
\text { Lewis Research Center } \\
\text { Cleveland, Ohio } 44135-3191\end{array}$} & \multicolumn{2}{|c|}{ 11. Contract or Grant No. } \\
\hline \multirow{2}{*}{\multicolumn{2}{|c|}{$\begin{array}{l}\text { 12. Sponsoring Agency Name and Address } \\
\text { National Aeronautics and Space Administration } \\
\text { Washington, D.C. } 20546-000 \mathrm{I}\end{array}$}} & \multicolumn{2}{|c|}{$\begin{array}{l}\text { 13. Type of Report and Period Covered } \\
\text { Technical Memorandum }\end{array}$} \\
\hline & & \multicolumn{2}{|c|}{ 14. Sponsoring Agency Code } \\
\hline \multicolumn{4}{|l|}{$\begin{array}{l}\text { 15. Supplementary Notes } \\
\text { Prepared for the } 31 \text { st Structures } \\
\text { ASME, AHS, and ASC, Long }\end{array}$} \\
\hline \multicolumn{4}{|l|}{$\begin{array}{l}\text { 16. Abstract } \\
\text { Composite specimens of titaniun } \\
\text { under a variety of thermal and } \\
\text { to estimate the effective in-situ } \\
\text { applied loads. Several fiber orie } \\
\text { composite stiffness varies with } \\
\text { uniaxial tension, thermal cycling } \\
\text { structural behavior, changes in }\end{array}$} \\
\hline $\begin{array}{l}\text { 17. Key Words (Suggested by Author(s)) } \\
\text { Metal matrix composites } \\
\text { Vibration } \\
\text { Experimental mechanics }\end{array}$ & $\begin{array}{r}\text { 18. Distribu } \\
\text { Unc } \\
\text { Sub }\end{array}$ & $\begin{array}{l}\text {-Unlimited } \\
\text { gory } 24\end{array}$ & \\
\hline $\begin{array}{l}\text { 19. Security Classif. (of this report) } \\
\text { Unclassified }\end{array}$ & $\begin{array}{l}\text { 20. Security Classif. (of this page) } \\
\text { Unclassified }\end{array}$ & $\begin{array}{c}\text { 21. No. of pages } \\
14\end{array}$ & $\begin{array}{l}\text { 22. Price* } \\
\mathrm{A03}\end{array}$ \\
\hline
\end{tabular}


ORIGINAL PAGE IS

OF POOR QUALITY

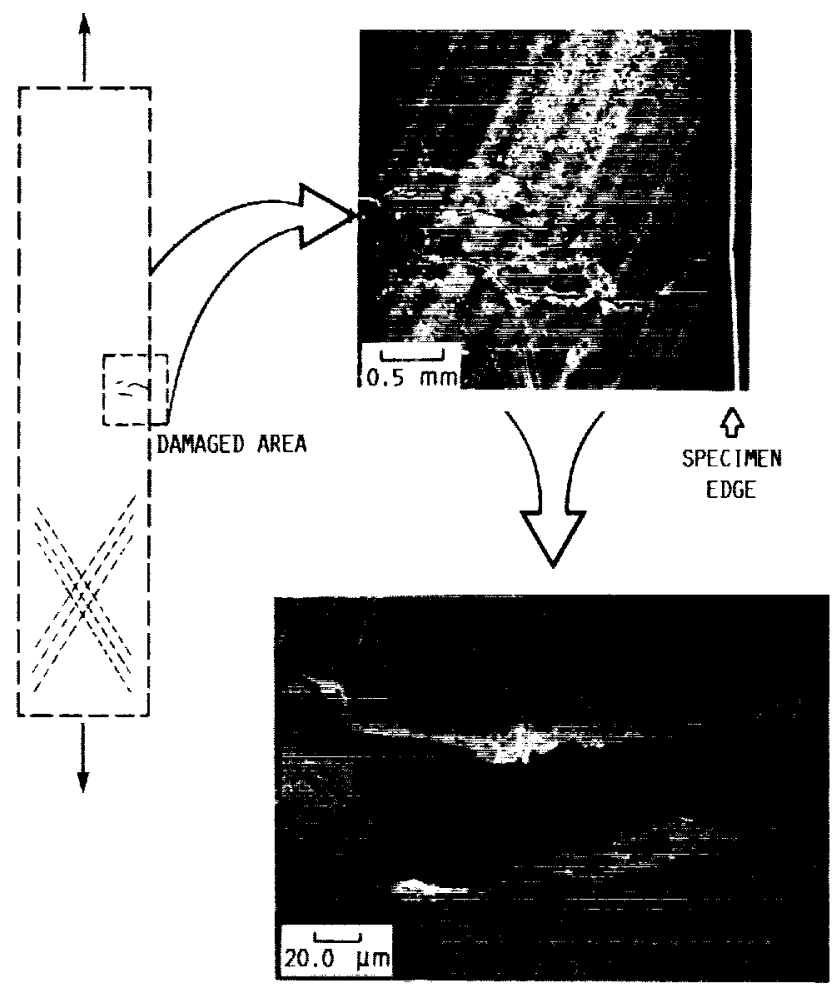

FIGURE 8. - SCANNING ELECTRON MICROSCOPE PHOTOGRAPHS OF DAMAGED AREA OF A $[ \pm 30]$ SPECIMEN LOADED IN TENSION TO 1.5 PERCENT STRAIN.
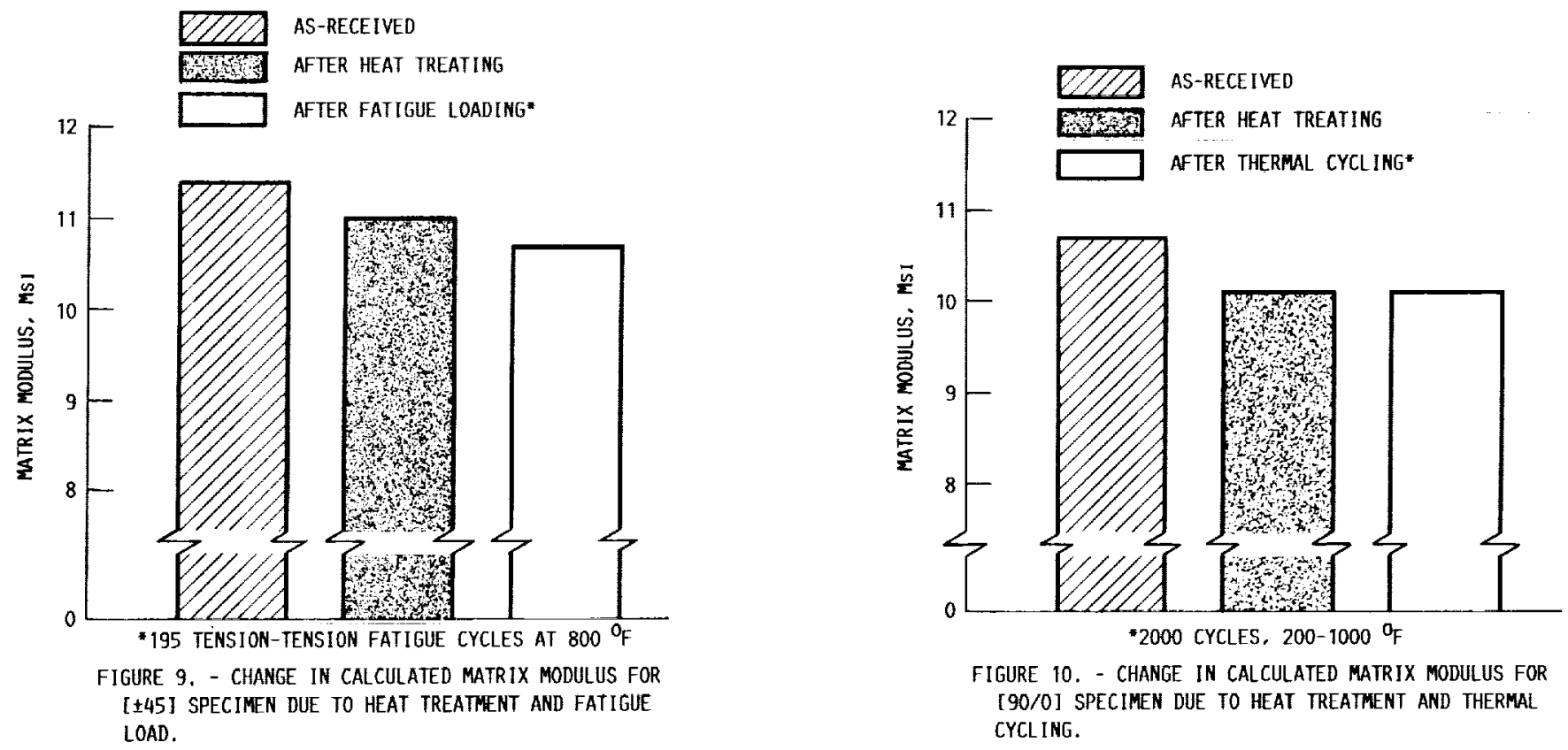